\title{
Psoriatic arthritis - classification, diagnostic and clinical aspects
}

\author{
Łuszczyca stawowa - klasyfikacja, aspekty diagnostyczne i kliniczne \\ Paweł Chabros', Aldona Pietrzak², Jacek Gągała', Grzegorz Kandzierski³, Dorota Krasowska² \\ 'Clinic of Orthopaedics and Traumatology, Orthopaedics Department, Medical University of Lublin, Lublin, Poland \\ 2Department of Dermatology, Venereology, and Paediatric Dermatology, Medical University of Lublin, Lublin, Poland \\ ${ }^{3}$ Orthopaedics and Peadiatric Rehabilitation Department, Univeristy Children's Hospital, Medical University of Lublin, Lublin, Poland \\ 'Klinika Ortopedii i Traumatologii, Katedra Ortopedii, Uniwersytet Medyczny w Lublinie, Lublin, Polska \\ ${ }^{2}$ Katedra i Klinika Dermatologii, Wenerologii i Dermatologii Dziecięcej, Uniwersytet Medyczny w Lublinie, Lublin, Polska \\ ${ }^{3}$ Klinika Ortopedii i Rehabilitacji Dziecięcej, Uniwersytecki Szpital Dziecięcy, Uniwersytet Medyczny w Lublinie, Lublin, Polska
}

Dermatol Rev/Przegl Dermatol 2020, 107, 32-43
DOI: https://doi.org/I 0.5 I | 4/dr.2020.93969

\author{
CORRESPONDING AUTHOR/ \\ ADRES DO KORESPONDENCJI: \\ Aldona Pietrzak \\ Katedra i Klinika Dermatologii, \\ Wenerologii i Dermatologii \\ Dziecięcej \\ Uniwersytet Medyczny \\ ul. Staszica 11 \\ 20-081 Lublin, Polska \\ tel.: +48 607305501 \\ e-mail: aldonkapietrzak@o2.pl
}

\begin{abstract}
From $5 \%$ to $40 \%$ patients with psoriatic skin lesions develop psoriatic arthritis, but $15 \%$ to $30 \%$ of patients with psoriasis suffer from undiagnosed psoriatic arthritis. The key role in development of psoriasis is played by T-lymphocytes and release of proinflammatory cytokines, interferon and adhesive proteins. Infection may exert an influence on psoriasis vulgaris and psoriatic arthritis development. The presence of antibodies against the antigens of Yersinia spp., Campylobacter spp. and Chlamydia trachomatis was more frequently observed in the serum of patients with psoriatic arthritis. Diagnosis of psoriatic arthritis may be based on CASPAR criteria. Diagnostic imaging (CT, MRI, USG) are routine diagnostic procedures in psoriatic arthritis. Several sub-types of psoriatic arthritis have been identified. Questionnaires to identify early stages of the disease have been constructed. Genetic factors, cigarette smoking, alcohol abuse, infections, stress and environmental factors may affect clinical course and results of treatment of psoriasis vulgaris and psoriatic arthritis. In severe cases, the disease may lead to disability.
\end{abstract}

\section{STRESZCZENIE}

U 5-40\% pacjentów z łuszczycą skóry występuje łuszczycowe zapalenie stawów, natomiast ok. 15-30\% pacjentów z łuszczycą skóry ma nierozpoznane łuszczycowe zapalenie stawów. Kluczową rolę w patogenezie łuszczycowego zapalenia stawów odgrywają limfocyty T oraz wydzielane przez nie prozapalne cytokiny (interleukiny, interferony) i białka adhezyjne. Zarówno w łuszczycy, jak i w łuszczycowym zapaleniu stawów ważna jest też rola czynnika infekcyjnego. W surowicy pacjentów z łuszczycowym zapaleniem stawów znacznie częściej obserwowano obecność przeciwciał przeciwko antygenom Yersinia spp., Campylobacter spp. oraz Chlamydia trachomatis. Rozpoznanie łuszczycowego zapalenia stawów może być oparte na kryteriach CASPAR. Badania obrazowe (TK, MRI, USG) stanowią rutynową diagnostykę w tej chorobie. Wyróżniono kilka podtypów łuszczycowego zapalenia stawów i wprowadzono kwestionariusze umożliwiające identyfikację ich wczesnych postaci. Na przebieg kliniczny oraz wyniki leczenia łuszczycowego zapalenia stawów istotny wpływ mogą mieć czynniki gene- 
tyczne, palenie papierosów, nadużywanie alkoholu, infekcje, stres oraz czynniki środowiskowe. W niektórych przypadkach choroba może prowadzić do inwalidztwa.

Key words: psoriasis, psoriatic arthritis, T-lymphocytes, proinflammatory cytokines, diagnosis, therapeutics.

Słowa kluczowe: łuszczyca, łuszczyca stawowa, limfocyty T, cytokiny prozapalne, diagnoza, leczenie.

\section{EPIDEMIOLOGY}

Psoriatic arthritis (PsA) is a seronegative arthritis. It occurs in $5-40 \%$ of patients suffering from psoriasis vulgaris. In 2015 PsA incidence was estimated to be at the level of 3.2/10,000 individuals [1]. Present epidemiological studies have not revealed differences in the incidence of PsA in men and women [2]. However, psoriasis involving spinal joints is more common in men, whereas the form resembling rheumatoid arthritis is more common in women [3].

Skin lesions in psoriasis usually precede joint lesions, however, in about $10-15 \%$ of cases joint lesions may precede skin lesions [4]. A connection between the extent and severity of skin lesions and the advancement level of joint lesions has not been confirmed [5]. Psoriatic arthritis may develop even during the first years of life. There are two clinical forms in children: 1) a form involving from 1 to 4 joints and developing mostly in girls aged 1-2; it is characterized by chronic uveitis and so-called "sausage digits"; and 2) a form involving a random number of joints that affects children of both sexes, who are usually aged 6-12; it is characterized by the presence of HLA-B27 antigen. A development of one type of paediatric PsA does not eliminate the possibility of developing the other one [6]. In accordance with PsA classification presented by International League of Association for Rheumatology (ILAR), PsA is different from other forms of juvenile idiopathic arthritis (JIA) and is defined by co-occurrence of arthritis and psoriasis with no other signs of JIA. A child suffering from arthritis and without a diagnosed psoriasis that has two or more of the following PsA symptoms meets the criteria for PsA: dactylitis, nail lesions, onycholysis, and history of psoriasis in the first-degree relatives [6]. A multi-joint form and high values of inflammatory parameters are considered to be predictive factors of joint damage [7].

\section{EPIDEMIOLOGIA}

Łuszczycowe zapalenie stawów (ŁZS, arthritis psoriatica) należy do seronegatywnych zapaleń stawów. Występuje u 5-40\% chorych na łuszczycę zwykłą. W 2015 roku występowanie ŁZS oszacowano na 3,2/10 000 osób [1]. Aktualne badania epidemiologiczne nie wykazały różnic w częstości zachorowań na ŁZS u mężczyzn i kobiet [2], jednak łuszczyca z zajęciem stawów kręgosłupa częściej występuje u mężczyzn, natomiast postać przypominająca reumatoidalne zapalenie stawów (RZS) u kobiet [3].

Zmiany skórne w przebiegu łuszczycy na ogół wyprzedzają zmiany stawowe, ale w ok. $10-15 \%$ przypadków może być odwrotnie [4]. Nie stwierdzono związku między rozległością i nasileniem zmian skórnych a stopniem zaawansowania zmian stawowych [5]. Łuszczycowe zapalenie stawów może pojawić się już w pierwszych latach życia. U dzieci wyróżnia się dwie postacie kliniczne: 1) postać obejmującą 1-4 stawów, występującą zwykle u dziewczynek w wieku od roku do 2 lat, która cechuje się przewlekłym zapaleniem błony naczyniowej i objawem palca kiełbaskowatego, oraz 2) postać zajmującą dowolną liczbę stawów i występującą u dzieci obu płci, zwykle w wieku 6-12 lat, która charakteryzuje się obecnością antygenu HLA-B27. Wystąpienie jednej postaci dziecięcego ŁZS nie wyklucza pojawienia się drugiej [6]. Według klasyfikacji Międzynarodowej Ligi Towarzystw Reumatologicznych (International League of Association for Rheumatology - ILAR) ŁZS różni się od innych form młodzieńczych idiopatycznych zapaleń stawów (MIZS) i jest definiowane jako współwystępowanie zapalenia stawów i łuszczycy przy braku cech innych MIZS. Dziecko z zapaleniem stawów bez zdiagnozowanej łuszczycy, które ma dwa lub więcej objawy ŁZS, takie jak zapalenie palców, zmiany paznokciowe, onycholiza, historia łuszczycy u krewnych pierwszego stopnia, spełnia kryteria ŁZS [6]. Za czynniki predykcyjne uszkodzenia stawów uznawane są postać wielostawowa i wysokie wartości parametrów stanu zapalnego [7]. 


\section{ETIOPATHOGENESIS}

The bottom and causes of inflammatory lesions within joints and entheses have not been fully discovered. It comes to bone marrow oedema in the area of entheses within the joints involved in the inflammation; whereas within the subchondral bone layers, macrophage and CD8 cytotoxic lymphocyte migration is increased and infiltrates appear [8]. PsA etiopathogenesis takes into account genetic, immunological, environmental, and constitutional factors [9, 10]. Genetic studies allowed for separating two main types of psoriasis. Type 1 is strongly coupled with histocompatibility antigens such as HLA-Cw6 that is present in psoriasis in $60-65 \%$ of cases, HLA-B57, DR7, HLA-Cw7, HLA-B13, and HLA-B39. Individuals with HLA-Cw6 gene found on PSORS1, a psoriasis susceptibility locus localized on chromosome 6 , are especially susceptible to develop psoriatic arthritis $[11,12]$. This type of psoriasis usually affects individuals younger than $40 \mathrm{y} / \mathrm{o}$, usually within one family, and extensive psoriatic lesions characterize it. Type 2 usually involves joints and nails; the first symptoms develop in individuals older than $40 \mathrm{y} / \mathrm{o}$. This type is less genetically conditioned; environmental factors are most frequently listed as the cause. Psoriatic arthritis is often concomitant with HLA-B27 antigen [11, 13-15].

Environmental factors, especially infections, are also important in PsA pathogenesis. Significantly higher levels of antibodies against Yersinia enterocolitica, Yersinia pseudotuberculosis, Campylobacter jejuni, and Campylobacter fetus as well as Chlamydia trachomatis antigens were observed [16]. HIV-infections in PsA-patients induce the development of treatmentresistance severe erosive forms of the disease [17] PsA development may be stimulated by hepatitis $C$ virus [18].

Furthermore, it was observed that high body mass index (BMI) is associated with an increased risk of developing PsA, and obesity in young adults is an independent risk factor for the risk of developing the disease [19]. Adipose tissue produces resistin, a polypeptide that plays an important role in insulin-resistance. It was proved that intensity of joint lesions in PsA correlated with an increased resistin concentration in blood serum and synovial fluid [20]. Obesity is associated with an overproduction of proinflammatory cytokines such as interleukin 1 (IL-1), IL-6, IL-8, and tumour necrosis factor (TNF) that exert an influence on PsA exacerbation [21]. Usage of NSAIDs may have an influence on exacerbation of PsA [22].

Psoriatic arthritis is more common in individuals with psoriatic lesions found on the gluteal furrow, scalp, and nail plates. Also, a connection between PsA and extent of skin lesions is possible. Researchers

\section{ETIOPATOGENEZA}

Podłoże i przyczyny zmian zapalnych $\mathrm{w}$ obrębie stawów i przyczepów ścięgnistych nie są do końca poznane. W stawach objętych procesem zapalnym dochodzi do obrzęku szpiku kostnego w okolicy przyczepów ścięgnistych, natomiast $\mathrm{w}$ warstwie podchrzęstnej kości do wzmożonej migracji makrofagów i limfocytów cytotoksycznych CD8 i powstawania nacieków [8]. W etiopatogenezie $€ Z S$ bierze się pod uwagę czynniki genetyczne, immunologiczne, środowiskowe oraz konstytucjonalne $[9,10]$. Badania genetyczne pozwoliły na wyodrębnienie dwóch głównych typów łuszczycy. Typ 1 jest silnie sprzężony z antygenami zgodności tkankowej, takimi jak HLA-Cw6, który wspólistnieje z łuszczycą w 60-65\% przypadków, a także HLA-B57, DR7, HLA-Cw7, HLA-B13 i HLA-B39. Szczególnie podatne na wystąpienie łuszczycy stawowej są osoby z genem HLA-Cw6 znajdującym się na PSORS1, loci podatności na łuszczycę (psoriasis susceptibility locus) zlokalizowanym na chromosomie $6[11,12]$. Ten typ łuszczycy występuje na ogół przed 40. rokiem życia, często rodzinnie, i charakteryzuje się rozległymi zmianami łuszczycowymi. Typ 2 przebiega zwykle z zajęciem stawów i paznokci, a pierwsze objawy pojawiają się po 40. roku życia. Ten typ choroby jest w mniejszym stopniu uwarunkowany genetycznie; jako przyczyny najczęściej wymienia się czynniki środowiskowe. Łuszczycowe zapalenie stawów często wspótistnieje także $z$ antygenem HLA-B27 [11, 13-15].

$W$ patogenezie $€ Z S$ ważne są także czynniki środowiskowe, zwłaszcza infekcje. Zaobserwowano istotnie wyższe poziomy przeciwciał przeciwko antygenom Yersinia enterocolitica, Yersinia pseudotuberculosis, Campylobacter jejuni, Campylobacter fetus oraz Chlamydia trachomatis [16]. Zakażenie wirusem HIV u chorych na ŁZS indukuje rozwój opornych na leczenie, ciężkich, nadżerkowych postaci tej choroby [17]. Rozwój ŁZS może stymulować wirus zapalenia wątroby typu $C$ [18].

Zaobserwowano także, że wysoki wskaźnik masy ciała (body mass index - BMI) wiąże się z podwyższonym ryzykiem wystąpienia ŁZS, a otyłość w okresie wczesnej dorosłości jest niezależnym czynnikiem ryzyka wystąpienia tej choroby [19]. Tkanka tłuszczowa produkuje rezystynę, polipeptyd odgrywający istotną rolę w insulinooporności. Stwierdzono, że nasilenie zmian stawowych w ŁZS koreluje z podwyższonym stężeniem rezystyny $\mathrm{w}$ surowicy oraz $\mathrm{w}$ płynie stawowym [20]. Otyłość jest związana z nadprodukcją cytokin prozapalnych, takich jak interleukina 1 (IL-1), IL-6, IL-8 oraz czynnik martwicy nowotworu (TNF), które wpływają na zaostrzenie ŁZS [21]. Stosowanie niesteroidowych leków przeciwzapalnych może powodować zaostrzenie ŁZS [22]. Łuszczycowe zapalenie stawów częściej występuje także u osób ze zmianami łuszczycowymi zlokalizowanymi w bruździe pośladków, na skórze owłosionej głowy i na płytkach 
suggest that it may be associated with abundant bacterial flora at those sites that triggers an immunological reaction leading to the development of psoriatic arthritis [15, 23].

It was proved that inflammation in the psoriatic skin, bone marrow, and the intestine is connected with the inflammation of the enthesis, synovitis, and changed skin phenotype. Within skin lesions, DNA is released by keratinocytes. After the binding of the released DNA with a bactericidal LL-37 peptide, interferon $\alpha$ a (INF- $\alpha$ ) is secreted by plasmacytoid dendritic cells. Then, dermal dendritic cells are activated and migrate to lymph nodes draining the changed area. Th1 and Th17 lymphocytes, which activate release of proinflammatory factors in the dermis: IL12, IL-17, and IL-22 (IL-12, IL-17, lymphoid cell and CD8+ T-lymphocytes cause an additional IL-17 secretion in the dermis), are then differentiated. Secretion of cytokines in the skin promotes proliferation of keratinocytes that in return secrete cytokines paracrinally and affect cells in the dermis. Within the bone marrow, there is a similar expansion of Th1 and Th17 cells, and other type 17 cells, as well as octacalcium (OCP) precursors. Then, IL-23 secretion and stimulation of type 17 cells are triggered. In case of enthesis, IL-23 secretion happens due to biomechanical stressinducing factors or a tendon injury at the enthesis. Type 17 cells are activated, and cytokines such as IL-22 and TNF start to be secreted, what results in an inflammation that exerts an influence on differentiation of mesenchymal cells into osteoblasts [6].

Enthesophytes - bony projections - form in peripheral attachments, whereas syndesmophytes bony bridges - form in the spine. Then, type 17 cells, $\mathrm{OCP}$, and dendritic cells from adjacent entheses or bloodstream end up in the joint. An increased expression of receptor activator of nuclear factor- $\kappa \mathrm{B}$ ligand (RANKL) caused by synoviocytes in the lining and an increased level of TNF, IL-17, and RANKL due to an increased expression caused by infiltrating cells, accelerated differentiation of OCP into osteoblasts. Consequently, synovitis and bone resorption develop [6].

Moreover, proinflammatory cytokines such as IL-1, IL-6 and molecules belonging to TNF family play a significant role in bone destruction $[6,24]$. They stimulate osteoblastogenesis, are inhibitors of proteoglycan synthesis, induce collagen and cartilage degradation by activating metalloproteinases and prostaglandin E2 [6, 24].

\section{CLINICAL PRESENTATION}

Psoriatic arthritis clinical symptoms include pain felt in the spine and involved joints, chronic enthesopathy, peripheral joint inflammation in the upper and lower limbs, and lesions in the nail plate $[6,24,25]$. The paznokciowych. Możliwa jest zależność pomiędzy ŁZS a rozległością zmian skórnych. Badacze sugerują, że może być to związane z obfitą florą bakteryjną w tych miejscach, która wywołuje reakcję immunologiczną prowadzącą do rozwoju ŁZS [23, 15].

Wykazano, że stan zapalny występujący w skórze łuszczycowej, szpiku kostnym i jelicie łączy się z zapaleniem przyczepu ścięgnistego, zapaleniem błony maziowej oraz zmienionym fenotypem kości. W wykwitach na skórze dochodzi do uwolnienia DNA przez keratynocyty. Po związaniu uwolnionego DNA z bakteriobójczym peptydem LL-37 następuje wydzielanie interferonu $\alpha$ (INF- $\alpha$ ) przez plazmocytoidalne komórki dendrytyczne. Dochodzi do zaktywowania dermalnych komórek dendrytycznych i ich migracji do drenujących zmienioną okolicę węzłów chłonnych. Następuje różnicowanie się limfocytów Th1 i Th17, które aktywują uwalnianie w skórze właściwej czynników prozapalnych: IL-12, IL-17 i IL-22 (IL-12, IL-17, komórki limfoidalne oraz limfocyty T CD8+ powodują dodatkowe wydzielanie IL-17 w skórze właściwej). Uwalnianie cytokin w skórze promuje proliferację keratynocytów, które zwrotnie wydzielają cytokiny parakrynnie oddziałujące na komórki w skórze właściwej. W szpiku kostnym dochodzi do podobnej ekspansji komórek Th1 i Th17 oraz innych komórek typu 17, a także prekursorów osteoklastów (OCP). Następuje uruchomienie wydzielania IL-23 oraz pobudzenie komórek typu 17. W przypadku przyczepu ścięgnistego wydzielanie IL-23 zachodzi wskutek biomechanicznych czynników stresogennych lub urazu ścięgna w punkcie przyczepu. Pojawia się aktywacja komórek typu 17 i wydzielanie cytokin, takich jak IL-22 i TNF, co skutkuje stanem zapalnym, który wpływa na różnicowanie się komórek mezenchymalnych w osteoblasty [6].

W obwodowych przyczepach i ścięgnach tworzą się entezofity - wyrośla kostne, a w kręgosłupie syndesmofity - mostki kostne. Komórki typu 17, OCP i komórki dendrytyczne z przyległych przyczepów ścięgnistych lub krwiobiegu trafiają do stawu. Zwiększona ekspresja liganda receptora aktywującego jądrowy czynnik NF- $\mathrm{B}$ (receptor activator of nuclear factor kappa-B ligand - RANKL) przez synowiocyty w wyściółce oraz podniesiony poziom TNF, IL-17 i RANKL wskutek zwiększonej ekspresji przez komórki naciekające przyspiesza różnicowanie OCP w osteoblasty. Skutkuje to zapaleniem błony maziowej i resorpcją kości [6].

Dużą rolę w destrukcji kości odgrywają też cytokiny prozapalne, takie jak IL-1, IL-6 oraz cząsteczki należące do rodziny TNF $[6,24]$. Stymulują one osteoklastogenezę, hamują osteoblastogenezę, są inhibitorami syntezy proteoglikanu, indukują degradację kolagenu i chrząstki przez aktywację metaloproteinaz i prostaglandyny E2 [6, 24]. 
Group for Research and Assessment of Psoriasis and Psoriatic Arthritis (GRAPPA) isolated several types of PsA with regard to the level of disease severity and clinical presentation associated with that. The classification facilitates making therapeutic decisions [26-28].

The GRAPPA classification is based on the knowledge of joint structure and an ability to find lesions in them (fig. 1) [25].

\section{DIAGNOSTIC CRITERIA}

Diagnosing PsA is based on Classification Criteria for Psoriatic Arthritis (CASPAR) criteria from 2006 (table 1) [29]. According to them, PsA is diagnosed

\section{OBRAZ KLINICZNY}

Do objawów klinicznych ŁZS należą: przewlekły ból kręgosłupa oraz zajętych stawów, przewlekła entezopatia, zapalenie stawów obwodowych kończyn górnych i dolnych oraz zmiany płytki paznokciowej [6, 24, 25]. Grupa do Badań Naukowych oraz Oceny Łuszczycy i Łuszczycowego Zapalenia Stawów (Group for Research and Assessment of Psoriasis and Psoriatic Arthritis - GRAPPA) wyodrębniła kilka postaci ŁZS ze względu na stopień ciężkości choroby oraz związany z nim obraz kliniczny. Podział ten ułatwia podejmowanie decyzji terapeutycznych [26-28].
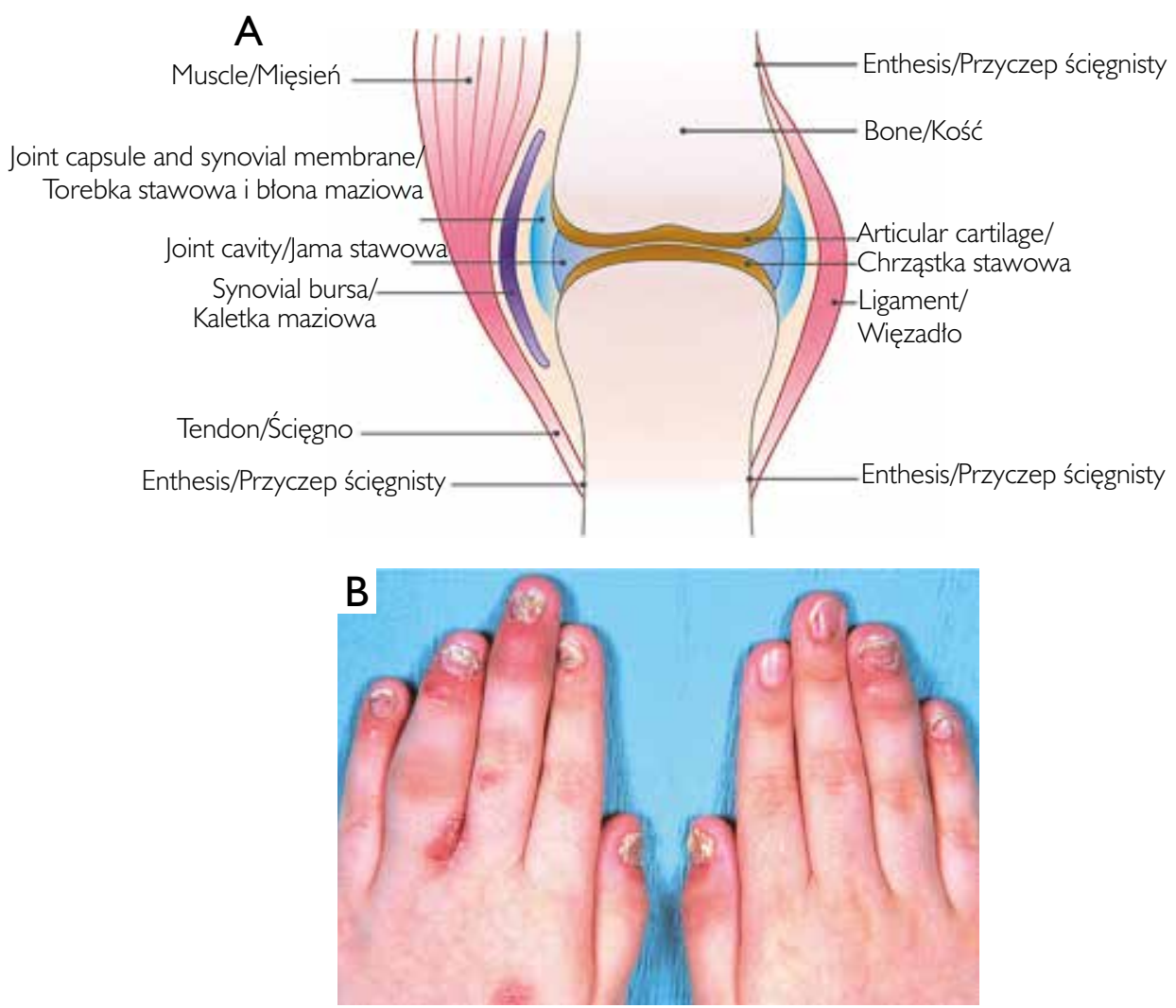

Figure I. Schematic representation of joint structure (A) and photograph showing typical symptoms of psoriatic arthritis (B) - Vlam K. et al., 2014 - reproduced with authors' permission [25]

Rycina I. Schemat budowy stawu (A) i zdjęcie typowych objawów w łuszczycowym zapaleniu stawów (B) - Vlam K. i wsp., 2014 za zgodą autorów [25]

Table I. Diagnostic criteria for psoriatic arthritis (CASPAR) [29]

\begin{tabular}{lc}
\hline Presence of current psoriatic lesions on the skin or occiput confirmed upon physical examination & 2 points \\
\hline History of psoriasis documented by the patient & | point \\
\hline Psoriasis in the first- and second-degree relatives & | point \\
\hline Nail lesions involving the matrix and nail bed (onycholysis, valleculae in the nail plate, hyperkeratosis) & | point \\
\hline Negative test for a rheumatoid factor (ELISA) & I point \\
\hline Dactylitis, i.e. sausage fingers currently or in history & | point \\
\hline New bone deformations visible in radiological examination: lesions within sternoclavicular joints, joints in hand and feet & I point \\
\hline that resemble periarticular proliferative lesions and have blurred rims & \\
\hline
\end{tabular}


Tabela I. Kryteria diagnostyczne łuszczycowego zapalenia stawów (CASPAR) [29]

\begin{tabular}{l}
\hline Obecność aktualnych zmian łuszczycowych na skórze lub potylicy stwierdzona w badaniu fizykalnym \\
\hline Historia łuszczycy udokumentowana przez pacjenta \\
\hline Łuszczyca u krewnych pierwszej i drugiej linii \\
\hline $\begin{array}{l}\text { Zmiany paznokciowe obejmujące macierz i łożysko paznokcia (onycholiza, zagłębienia w płytce paznokciowej, } \\
\text { hiperkeratoza) }\end{array}$ \\
\hline Negatywny wynik testu metodą ELISA na obecność czynnika reumatoidalnego \\
\hline Zapalenie palców (dactylitis), czyli tzw. palce kiełbaskowate, obecnie lub w wywiadzie \\
\hline Nowe deformacje kości widoczne w badaniu radiologicznym: zmiany w obrębie stawów mostkowo-obojczykowych, \\
stawów rąk i stóp w postaci okołostawowych zmian proliferacyjnych, nieostro odgraniczonych
\end{tabular}

when a patient suffers from peripheral joint inflammation, spondyloarthritis or sacroiliitis, enthesopathy, and he/she achieved $\geq 3$ points according to CASPAR classification $[5,29,30]$. CASPAR classification allows for diagnosing PsA in patients without skin lesions.

\section{DISEASE FORMS}

In 2009 Assessment of Spondyloarthritis International Society (ASAS) isolated axial and peripheral forms of PsA [31]. Axial PsA is diagnosed on the basis of radiologic criteria in case of unilateral sacroiliitis, whereas peripheral PsA involves peripheral joints, tendon attachments, capsular ligaments, and fasciae.

Duration and symptom intensification in PsA are very variable what makes correct clinical classification difficult. Forms of PsA may be concurrent or develop one after another during different periods of the disease [32]. PsA forms classified with regard to lesion exacerbation are presented in table 2 [33].

\section{ASSESSMENT OF SEVERITY}

PsA severity assessment includes [5, 34-39]:

1. Number of painful (68 possible) and oedematous (66 possible) joints.
Podział GRAPPA opiera się na znajomości budowy stawów oraz wiedzy na temat możliwości lokalizacji zmian w ich obrębie (ryc. 1) [25].

\section{KRYTERIA ROZPOZNANIA}

Rozpoznanie ŁZS opiera się na kryteriach CASPAR (Classification Criteria for Psoriatic Arthritis) z 2006 roku (tab. 1) [29]. Według nich ŁZS rozpoznaje się, gdy pacjent ma zapalenie stawów obwodowych, zapalenie stawów kręgosłupa lub zapalenie stawów krzyżowo-biodrowych, entezopatie oraz uzyska co najmniej 3 pkt w klasyfikacji CASPAR [5, 29, 30]. Na podstawie klasyfikacji CASPAR możliwe jest rozpoznanie $\mathrm{ZS} \mathrm{u}$ chorych bez zmian skórnych.

\section{POSTACIE CHOROBY}

W 2009 roku grupa ASAS (Assessment of SpondyloArthritis International Society) wyodrębniła postać osiową i obwodową ŁZS [31]. Postać osiową rozpoznaje się na podstawie kryteriów radiologicznych w przypadku jednostronnego zapalenia stawów krzyżowo-biodrowych, natomiast postać obwodowa obejmuje stawy obwodowe, przyczepy ścięgien, więzadła torebki stawowej oraz powięzie.

Table 2. Classification of psoriatic arthritis with regard to lesion intensity [33]

\begin{tabular}{|c|c|c|c|c|c|}
\hline $\begin{array}{l}\text { Psoriatic } \\
\text { arthritis }\end{array}$ & $\begin{array}{l}\text { Number of involved } \\
\text { joints }\end{array}$ & $\begin{array}{l}\text { Number of entheses with } \\
\text { signs of inflammation }\end{array}$ & Radiological picture & $\begin{array}{l}\text { Skin symptoms } \\
\text { (PASI) }\end{array}$ & $\begin{array}{l}\text { Quality } \\
\text { of life }\end{array}$ \\
\hline Mild & $<5$ & $1-2$ & $\begin{array}{l}\text { As the disease progresses, } \\
\text { lesions occur }\end{array}$ & - & - \\
\hline Moderate & $\geq 5$ & $>2$ & + & $<10$ & $\downarrow$ \\
\hline Severe & $\geq 5$ & $>2$ & ++ & $>10$ & $\downarrow$ \\
\hline
\end{tabular}

Tabela 2. Podział łuszczycowego zapalenia stawów w zależności od stopnia nasilenia zmian [33]

\begin{tabular}{lcccc}
$\begin{array}{l}\text { Postać } \\
\text { łuszczycowego } \\
\text { zapalenia stawów }\end{array}$ & $\begin{array}{c}\text { Liczba zajętych } \\
\text { stawów }\end{array}$ & $\begin{array}{c}\text { Liczba przyczepów } \\
\text { ścięgnistych z objawami } \\
\text { zapalenia }\end{array}$ & Obraz radiologiczny & $\begin{array}{c}\text { Objawy } \\
\text { skórne (PASI) }\end{array}$ \\
Łagodna & $<5$ & $1-2$ & $\begin{array}{c}\text { J miarę postępu choroby życia } \\
\text { pojawiają się zmiany }\end{array}$ & - \\
\hline Umiarkowana & $\geq 5$ & $>2$ & + & $<10$ \\
\hline Ciężka & $\geq 5$ & $>2$ & ++ & $\downarrow 10$ \\
\hline
\end{tabular}


2. Pain intensity assessed by a patient on VAS: 0-10 points, where 0 means no pain, and 10 means the highest imaginable pain.

3.Quality of life: Health Assessment Questionnaire Score (HAQ-SK), Psoriatic Arthritis Quality of Life (PsAQoL), Dermatology Life Quality Index (DLQI), and EuroQol 5-domain (EQ-5D).

4. Patient's general self-assessment (psychical, physical, and social aspects): Short Form-36 (SF-36), and Beck Depression Inventory - Short Form (BDI).

5. Level of inflammation severity assessed by means of inflammatory parameters present in peripheral blood: e.g. acute phase protein, ESR.

6. Level of intensity, activity of the disease, and pain assessed with the use of Bath Ankylosing Spondylitis Disease Activity Index (BASDAI) or Likert scale. Questionnaires allowing for identification of early PsA forms have been devised. Four such tools are available: Psoriatic Arthritis Screening and Evaluation (PASE) [38] that is used for screening tests for PsA; Psoriasis Epidemiology Screening Tool (PEST) [40] used to identify individuals with PsA within a group of psoriatic patients; Toronto Psoriatic Arthritis Screen (ToPAS II) [41] that is a promising instrument for early diagnosis of PsA in both psoriatic patients and general population; and Early Psoriasic Arthritis Screening Questionnaire (EARP) that not only does allow for early identification of PsA in psoriatic patients, but also enables the assessment of the severity level of this disease [42].

\section{DIAGNOSTIC IMAGING}

Classic radiography is useful in assessing the severity of joint lesions, because a radiological picture characteristic for PsA, including joint space narrowing, erosions within synovial joints (e.g. knee joints) as well as cartilaginous and fibrous joints (e.g. sacroiliac joints), and inflammatory lesions of tendon attachments and ligaments, are confirmed only in advanced stages of the disease [32]. Differentiation between bone erosions present in PsA and bone erosions present in rheumatoid arthritis is possible only with the use of high-resolution computed tomography, magnetic resonance imaging, or ultrasound exam $[43,44]$. If the disease progresses, the erosions deepen, and proliferative reactions with formation of enthesophytes and osteophytes develop; also, joint destruction occurs. Furthermore, generalized osteoporosis may develop. A characteristic feature of peripheral psoriatic arthritis is asymmetry of lesions and simultaneous concomitance of ankylosis and osteolysis within joints found in the same area, e.g. foot or hand [32].

A feature that differentiated PsA from other joint inflammations within the spine is a large extent of radiological lesions, their significant size, and asym-
Czas trwania i nasilenie objawów w ŁZS są bardzo zmienne, co utrudnia właściwą klasyfikację kliniczną. Postacie ŁZS mogą występować jednocześnie lub następować po sobie w różnych okresach trwania choroby [32]. Postaci ŁZS w zależności od stopnia nasilenia zmian przedstawiono $\mathrm{w}$ tabeli 2 [33].

\section{OCENA STOPNIA ZAAWANSOWANIA}

Ocena stopnia zaawansowania ŁZS obejmuje [5, 34-39]:

1) liczbę bolesnych (na 68 możliwych) i obrzękniętych stawów (na 66 możliwych),

2) nasilenie bólu oceniane przez chorego w skali analogowej VAS od 0 do 10 pkt, gdzie 0 oznacza całkowity brak bólu, a 10 - największy wyobrażalny ból,

3) ocenę jakości życia - kwestionariusze: HAQ-SK (Health Assessment Questionnaire Score), PsAQoL (Psoriatic Arthritis Quality of Life), DLQI (Dermatology Life Quality Index) i EQ-5D (EuroQol 5-domain), 4) ogólną samoocenę pacjenta (aspekty psychiczne, fizyczne, społeczne) - kwestionariusz SF-36 (Short Form-36) oraz Inwentarz depresji Becka (BDI; Beck Depression Inventory - Short Form),

5) stopień nasilenia stanu zapalnego oceniany za pomocą parametrów zapalnych obecnych we krwi obwodowej, np. białka ostrej fazy, OB,

6) aktywność procesu chorobowego i stopień nasilenia bólu oceniane w skali BASDAI (Bath Ankylosing Spondylitis Disease Activity Index) lub skali Likerta. Opracowano kwestionariusze umożliwiające identyfikację wczesnych postaci ŁZS. Dostępne są cztery takie narzędzia: kwestionariusz PASE (Psoriatic Arthritis Screening and Evaluation) [38] służący do badań przesiewowych w kierunku ŁZS, kwestionariusz PEST (Psoriasis Epidemiology Screening Tool) [40] stosowany do identyfikacji osób z ŁZS wśród chorych na łuszczycę; kwestionariusz ToPAS II (Toronto Psoriatic Arthritis Screen) [41] do wczesnej diagnostyki ŁZS u chorych na łuszczycę i w populacji ogólnej; kwestionariusz EARP (Early Psoriatic Arthritis Screening Questionnaire) umożliwiający nie tylko wczesną identyfikację ŁZS u chorych na łuszczycę, lecz także ocenę stopnia zaawansowania tej choroby [42].

\section{BADANIA OBRAZOWE}

Klasyczna radiografia jest przydatna w ocenie zaawansowanych zmian stawowych, ponieważ charakterystyczny dla ŁZS obraz radiologiczny, taki jak zwężenie szpar stawowych, nadżerki w obrębie stawów maziówkowych (np. stawy kolanowe) i chrzęstno-włóknistych (np. stawy krzyżowo-biodrowe) oraz zmiany zapalne przyczepów ścięgien i więzadeł, stwierdza się dopiero w zaawansowanych postaciach choroby 
metrical placement with omission of some vertebrae [14]. Radiological lesions in psoriasis of the spine that take the form of "flocky" ossifications parallel to lateral surfaces of vertebral bodies are called parasyndesmophytes. They appear already in early stages of PsA. Advanced psoriasis of the spine may take the form of a "bamboo spine", similarly to ankylosing spondylitis (AS), or manifest itself as vertebral squaring, ankylosis of facet joints, and ossification of joint ligaments [37].

Within the course of psoriatic arthritis the most characteristic is an early involvement of iliac side of the sacroiliac joint, asymmetry of the lesions or their unilateral location. At early stages, the following appear: shallow erosions, subchondral sclerotization, and segmental widening of the joint space. At later stages, proliferative lesions lead to developments of bone bridges, narrowing of the joint space, and ankylosis [37]. Dynamic contrast-enhanced magnetic resonance (DCE-MRI) allows for determining the level of vascularization in the bone marrow, what is an indirect indicator of inflammation activity. A characteristic symptom for PsA visible in DCE-MRI is inflammation of periarticular soft tissues at early stages of the disease, which may occur without a visible synovitis. A full-body MRI may be useful. The application of this exam along with ultrasound allows for identifying active inflammatory lesions within joints in about $80 \%$ of PsA-patients when there are no clinical signs [14, 32, 34, 43-45]. Epidemiological observations showed that erosive form of the disease develops in about half of untreated patients with early PsA 2 years after the diagnosis [7].

\section{THERAPEUTIC PROCEDURES}

Newest guidelines of European League Against Rheumatism (EULAR), published in 2017 and regarding treatment of both early and advanced forms of PsA, include the following $[28,46]$ :

1. A patient that has symptoms of arthritis should be examined by a rheumatologist not later than 6 weeks from the appearance of the symptoms.

2. A physical examination is a method of choice in early PsA diagnostics. The diagnosis may be confirmed by ultrasound, computed tomography or magnetic resonance imaging.

3. If the final diagnosis cannot be made on the basis of physical examination and imagining, and the patient has early symptoms of arthritis and is at risk of recurrent or chronic erosive arthritis expressed by the number of involved joints, presence of rheumatoid factor, acute-phase proteins as well as anticitrullinated peptide (anti-CPP) autoantibodies, and diagnostic imagining test results, a treatment involving conventional synthetic disease-modify-
[32]. Różnicowanie nadżerek kostnych występujących w przebiegu ŁZS z nadżerkami kostnymi w przebiegu reumatoidalnego zapalenia stawów jest możliwe tylko przy użyciu tomografii komputerowej o wysokiej rozdzielczości, rezonansu magnetycznego lub badania ultrasonograficznego [43, 44]. Jeżeli choroba postępuje, dochodzi do pogłębienia nadżerek, rozwoju odczynów proliferacyjnych z powstawaniem entezofitów i osteofitów oraz destrukcji stawu. Może się także rozwinąć uogólniona osteoporoza. Cechą charakterystyczną obwodowej łuszczycy stawowej jest asymetria zmian oraz jednoczesne występowanie ankylozy i osteolizy w stawach tej samej okolicy, np. stopy lub ręki [32].

Cechą odróżniającą ŁZS od innych zapaleń stawów w obrębie kręgosłupa jest duża rozległość zmian radiologicznych, ich znaczne rozmiary oraz asymetryczne rozmieszczenie $\mathrm{z}$ pominięciem niektórych kręgów [14]. Zmiany radiologiczne w łuszczycy kręgosłupa w postaci „kłaczkowatych” skostnień, układających się równolegle do bocznej powierzchni trzonów kręgowych, są określane mianem parasyndesmofitów. Pojawiają się one już we wczesnym okresie ŁZS. Zaawansowana łuszczyca kręgosłupa może mieć postać „kija bambusowego”, podobnie jak w zesztywniającym zapaleniu stawów kręgosłupa (ZZSK), lub objawiać się kwadratowieniem trzonów kręgowych, ankylozą stawów międzywyrostkowych i kostnieniem więzadeł stawowych [37].

W przebiegu łuszczycy stawowej najbardziej charakterystyczne jest wczesne zajęcie biodrowej strony stawu krzyżowo-biodrowego, asymetria zmian chorobowych lub ich jednostronna lokalizacja. W początkowym okresie choroby powstają płytkie nadżerki, dochodzi do podchrzęstnej sklerotyzacji i odcinkowego poszerzenia szpary stawowej. Później zmiany proliferacyjne prowadzą do tworzenia się mostków kostnych, zwężenia szpar stawowych i ankylozy [37]. Badanie dynamiczne metodą rezonansu magnetycznego $\mathrm{z}$ podaniem kontrastu (dynamic contrast-enhanced magnetic resonance - DCE-MRI) umożliwia określenie stopnia unaczynienia szpiku kostnego, co jest pośrednim wskaźnikiem aktywności procesu zapalnego. Objawem charakterystycznym ŁZS widocznym w badaniu DCE-MRI jest zapalenie tkanek miękkich okołostawowych we wczesnych postaciach choroby, które może występować bez widocznego zapalenia błony maziowej. Użytecznym badaniem może być MRI całego ciała, które wraz z USG pozwala na identyfikację aktywnych zmian zapalnych w obrębie stawów u ok. $80 \%$ chorych na ŁZS mimo braku objawów klinicznych [14, 32, 34, 43-45]. Obserwacje epidemiologiczne wykazały, że u około połowy nieleczonych chorych $\mathrm{z}$ wczesną postacią $\mathrm{ZSS} \mathrm{w}$ czasie pierwszych 2 lat od momentu rozpoznania rozwija się postać nadżerkowa [7]. 
ing antirheumatic drugs (csDMARDs), e.g. methotrexate, leflunomide, or sulfasalazine, should be introduced.

4. Conventional treatment should be introduced not later than within 3 months from the appearance of symptoms, even if not all PsA criteria are met. In patients with recurrent or chronic arthritis, conventional therapy should be based on methotrexate given there are no contraindications (in such cases leflunomide, sulfasalazine, or apremilast are alternatives).

5. In patients with mild axial PsA that manifests itself clinically with back pain, but without limiting the function of spinal joints, it is recommended to use nonsteroidal anti-inflammatory drugs (NSAIDs), e.g. naproxen, indomethacin, and celecoxib. Nonsteroidal anti-inflammatory drugs should be used in minimal effective doses for the shortest time possible, and prior gastrological, nephrological, and cardiological assessment.

6. In patients with axial form that do not react to NSAISs and suffer from back pain and morning stiffness, it is recommended to use IL-17 or IL-23 inhibitors (secukinumab and ustekinumab respectively). Treatment efficacy in axial PsA is assessed by mean of BASDAI. The disease is considered active if $\mathrm{BASDAI} \geq 4$. BASDAI $<3$ or reduction with at least 2 points means that the applied treatment is effective.

7. Systemic glucocorticosteroids reduce joint pain and slower the process of their destruction, but due to the possibility of dose accumulation and potential side effects, the glucocorticosteroids should be use for a possibly short period of time (6 months maximum) in minimal doses. Intra-articular steroid injections in peripheral PsA should be used only in cases of significant exacerbation of general and local inflammation When introducing systemic glucocoticosteroids in patients with psoriasis or psoriatic arthritis it has to be considered that it may be associated with increased risk of developing generalised pustular psoriasis.

8. In peripheral PsA, an initial assessment of active inflammation is performed on the basis of guidelines presented at the $8^{\text {th }}$ Congress of OMERACT (Outcome Measures in Rheumatoid Arthritis Clinical Trials) prior to the treatment. The activity of inflammation should be assessed every 1, 2 or 3 months by means of laboratory and imaging tests as well as physical examination of the joints. If there is no significant improvement after 3 months of conventional therapy or the disease still involves more than 3 joints, it is recommended to apply biological treatment with first-line TNF inhibitors. If there is still no sufficient response to treatment, it is recommended to start a therapy with monoclonal

\section{POSTĘPOWANIE TERAPEUTYCZNE}

Najnowsze rekomendacje EULAR (European League Against Rheumatism), opublikowane w 2017 roku i dotyczące leczenia zarówno wczesnych, jak i zaawansowanych postaci ŁZS, są następujące [28, 46]:

1. Chory, który ma objawy zapalenia stawów, powinien być zbadany przez reumatologa najpóźniej w czasie 6 tygodni od wystąpienia tych objawów.

2. Badanie fizykalne jest metodą $\mathrm{z}$ wyboru w diagnostyce wczesnego ŁZS. Diagnoza może być potwierdzona przez USG, TK lub MRI.

3. Jeżeli ostateczna diagnoza nie może być postawiona na podstawie badania fizykalnego i badań obrazowych, a pacjent ma wczesne objawy zapalenia stawów oraz ryzyko wystąpienia nawracającego lub przewlekłego nadżerkowego zapalenia stawów wyrażone liczbą zajętych stawów, obecnością czynnika reumatoidalnego, obecnością białek ostrej fazy, obecnością autoprzeciwciał anty-CPP (anti-citrullinated peptide antibodies) oraz wynikami badań obrazowych, powinno się wdrożyć leczenie konwencjonalne csDMARDs (conventional synthetic disease-modyfying anti-rheumatic drugs), np. metotreksat, leflunomid, sulfasalazyna.

4. Leczenie konwencjonalne powinno być włączone najpóźniej w czasie 3 miesięcy od wystąpienia objawów, nawet jeśli nie są spełnione wszystkie kryteria ŁZS. U chorych z nawracającym lub przewlekłym zapaleniem stawów terapia konwencjonalna powinna być oparta na metotreksacie, jeżeli nie ma przeciwwskazań do jego zastosowania (alternatywą dla metotreksatu jest $\mathrm{w}$ takiej sytuacji leflunomid, sulfasalazyna lub apremilast).

5. U pacjentów z łagodną osiową postacią ŁZS objawiającą się klinicznie bólami pleców, ale bez ograniczenia funkcji stawów kręgosłupa, zaleca się stosowanie niesteroidowych leków przeciwzapalnych, np. naproksenu, indometacyny i celekoksybu. Niesteroidowe leki przeciwzapalne powinny być stosowane w minimalnej skutecznej dawce przez możliwie najkrótszy czas, po wcześniejszej ocenie gastrologicznej, nefrologicznej oraz kardiologicznej.

6. U chorych z osiową postacią $\mathrm{ZZS}$ niereagujących na niesteroidowe leki przeciwzapalne, z silnymi dolegliwościami bólowymi pleców i sztywnością poranną, zaleca się stosowanie inhibitorów IL-17 (sekukinumab) lub IL-23 (ustekinumab). Skuteczność leczenia w osiowej postaci ŁZS ocenia się na podstawie skali BASDAI. Chorobę uznaje się za aktywną przy BAS$\mathrm{DAI} \geq 4$. Wartość BASDAI < 3 lub redukcja o co najmniej 2 pkt świadczy o skuteczności stosowanego leczenia.

7. Glikokortykosteroidy ogólne redukują ból stawów oraz spowalniają proces ich destrukcji, ale ze względu na możliwość kumulacji dawki i potencjalne skutki uboczne powinny być stosowane możliwie krótko (maksimum 6 miesięcy) w minimalnej skutecznej 
antibodies (infliximab, adalimumab, golimumab, certolizumab, etanercept).

9. In patients with severe erosive PsA and signification limitations of joint functions, it is recommended to use TNF inhibitors as the first-line treatment, and in case they are not effective enough, to introduce biological drugs from other groups (secukinumab, ustekinumab).

Biological and bio-like drugs registered for use in PsA include TNF inhibitors (adalimumab, certolizumab, etanercept, golimumab, and infliximab), interleukin inhibitors (secukinumab, ustekinumab, ixekizumab), and tofacitinib that is a Janus kinase 1 and Janus kinase 3 inhibitor.

Criteria for assessment of response to treatment in axial and peripheral PsA include the following protocols: DAS28 (Disease Activity Score 28 Joints), ACR criteria [47], DAPSA (Disease Activity in Psoriatic Arthritis) [48], PASDAS (Psoriatic Arthritis Disease Activity Score) [49], mCPDAI (modified Composite Psoriatic Disease Activity Score) [50], and PsARC (Psoriatic Arthritis Response Criteria) [51]. In addition, it should be emphasized that apart from phonological treatment, early rehabilitation of locomotor system, quitting smoking, normalization of the body mass, oral cavity sanitization, and stabilization of possible concomitant diseases are necessary.

\section{CONCLUSIONS}

Early detection and treatment of PsA gives an opportunity for disease remission and prevention of joint destruction. Therapeutic and prophylactic decisions should consider the influence of the disease on patients' quality of life. Special attention should be paid to new biological drugs.

\section{CONFLICT OF INTEREST}

The authors declare no conflict of interest. dawce. Dostawowe iniekcje glikokortykosteroidów w obwodowej postaci ŁZS powinny być stosowane tylko w przypadku znacznego nasilenia ogólnych i miejscowych objawów zapalnych. Należy pamiętać, że stosowanie glikokortykosteroidów ogólnie u pacjentów z łuszczycą lub łuszczycowy zapaleniem stawów wiąże się z ryzykiem rozwoju łuszczycy krostkowej uogólnionej.

8. W postaci obwodowej ŁZS przed rozpoczęciem leczenia dokonuje się wstępnej oceny aktywności procesu zapalnego opartej na ustaleniach z 8. kongresu OMERACT (Outcome Measures in Rheumatoid Arthritis Clinical Trials). Aktywność procesu zapalnego powinna być oceniana co 1, 2 lub 3 miesiące za pomocą badań laboratoryjnych i obrazowych oraz badania fizykalnego stawów. Jeżeli nie ma istotnej poprawy po 3 miesiącach terapii konwencjonalnej lub proces chorobowy nadal obejmuje więcej niż 3 stawy, zaleca się leczenie biologiczne za pomocą inhibitorów TNF w pierwszej linii. Jeśli nadal nie ma wystarczającej odpowiedzi na leczenie, wskazana jest terapia przeciwciałami monoklonalnymi (infliksymab, adalimumab, golimumab, certolizumab, etanercept).

9. U pacjentów z ciężką, nadżerkową postacią ŁZS i znacznym ograniczeniem funkcji stawów zaleca się zastosowanie inhibitorów TNF w pierwszej linii leczenia, a w przypadku ich niewystarczającej skuteczności włączenie leków biologicznych z innych grup (sekukinumab, ustekinumab).

Spośród leków biologicznych i biopodobnych zarejestrowanych $\mathrm{w}$ leczeniu $Ł Z S$ można wymienić inhibitory TNF (adalimumab, certolizumab, etanercept, golimumab i infliksymab), inhibitory interleukin (sekukinumab, ustekinumab, iksekizumab), a także tofacytynib, który jest inhibitorem enzymu kinazy Janus 1 i kinazy Janus 3.

Kryteria oceny odpowiedzi na leczenie dla osiowej i obwodowej postaci ŁZS obejmują następujące protokoły: DAS28 (Disease Activity Score 28 Joints), ACR [47], DAPSA (Disease Activity in Psoriatic Arthritis) [48], PASDAS (Psoriatic Arthritis Disease Activity Score) [49], mCPDAI (modified Composite Psoriatic Disease Activity Score) [50] i PsARC (Psorisatic Arthritis Response Criteria) [51]. Należy podkreślić, że oprócz leczenia farmakologicznego konieczna jest wczesna rehabilitacja układu ruchu, zaprzestanie palenia tytoniu, normalizacja masy ciała, sanacja jamy ustnej oraz stabilizacja ewentualnych chorób współistniejących.

\section{WNIOSKI}

Wczesne wykrycie i leczenie ŁZS daje szansę na remisję choroby oraz może zapobiec destrukcji stawów. Decyzje terapeutyczne i profilaktyczne powinny uwzględniać wpływ na jakość życia chorego. Warto zwrócić szczególną uwagę na nowe leki biologiczne. 


\section{KONFLIKT INTERESÓW}

Autorzy nie zgłaszają konfliktu interesów.

\section{References}

\section{Piśmiennictwo}

1. Raciborski F., Śliwczyński A., Kłak A., Kwiatkowska B., Brzozowska M., Tłustochowicz M.: Prevalence of psoriatic arthritis and costs generated by treatment of psoriatic arthritis patients in the public health system - the case of Poland. Reumatologia 2016, 54, 278-284.

2. Pariser D., Schenkel B., Carter C., Farahi K., Brown T.M., Ellis C.N.: Psoriasis Patient Interview Study Group: a multicenter, non-interventional study to evaluate patient-reported experiences of living with psoriasis. J Dermatol Treat 2016, 27, 19-26.

3. Queiro R., Sarasqueta C., Torre J.C., Tinture T., Lopez-Lagunas I.: Comparative analysis of psoriatic spondyloarthropathy between men and women. Rheumatol Int 2001, 21, 66-68.

4. Gladman D.D., Antonic C., Mease P., Clegg D.O., Nash P.: Psoriatic arthritis: epidemiology, clinical features course and outcome. Ann Rheum Dis 2005, 64, 14-17.

5. Tłustochowicz W., Świerkot J., Stanisławska-Biernat E.: Łuszczycowe zapalenie stawów. Reumatologia 2016, 54, 22-25.

6. Ritchlin C.T., Colbert R.A., Gladman D.D.: Psoriatic arthritis. N Engl Med 2017, 376, 957-970.

7. Kleinert S., Feuchtenberger M., Kneitz C., Tony H.P.: Psoriatic arthritis: clinical spectrum and diagnostic procedures. Clin Dermatol 2007, 25, 519-523.

8. McGonagle D.: Enthesitis: an autoinflammatory lesion linking nail and joint involvement in psoriatic disease. J Eur Acad Derm Venereol 2009, 23, 9-13

9. Chandran V., Raychaudhuri S.P.: Geoepidemiology and environmental factors of psoriasis and psoriatic arthritis. J Autoimmun 2010, 34, 314-321.

10. Veale D.J.: Psoriatic arthritis: recent progress in pathophysiology and drug development. Arthritis Res Ther 2013, 15, $224-229$.

11. Ho P.Y., Barton A., Worthington J., Plant D., Griffiths C.E., Young H.S., et al.: Investigating the role of HLA-Cw*06 and HLA-DRB1 genes susceptibility to psoriatic arthritis. Ann Rheum Dis 2008, 67, 677-82.

12. Laws P., Barton A., Warren R.B.: psoriatic arthritis - what the dermatologist needs to know. J Eur Acad Derm Venereol 2010, 24, 127-77.

13. Griffiths C.E.M., Baker J.N.W.N.: Pathogenesis and clinical features of psoriasis. Lancet 2007, 370, 263-271.

14. Sudol-Szopińska I., Urbanik A.: Diagnostic imaging of sacroiliac joints and the spine in the course of spondyloarthropaties. Pol J Radiol 2013, 78, 43-49.

15. Odgie A., Weiss P.: The epidemiology psoriatic arthritis. Rheum Dis Clin North Am 2015, 41, 545-568.

16. Lapadula G., Iannone F., Covelli M., Numo R., Pipitone V.: Anti-enterobacteria antibodies in psoriatic arthritis. Clin Exp Rheumatol 1992, 10, 461-466.

17. Adizie T., Moots R.J., Hodkinson B., French N., Adebajo A.O.: Inflammatory arthritis in HIV-positive patients: a practical guide. BMC Inf Dis 2016, 16, 100.

18. Bomifati C., Lora V., Graceffa D., Nosottio L.: Management of psoriasis patients with hepatitis B or hepatitis C virus infection. World J Gastroemterol 2016, 22, 6444-6455.

19. Soltani-Arabshahi R., Wong B., Feng B.J., Goldgar D.E., Duffin K.C., Krueger G.G.: Obesity in early adulthood as a risk factor for psoriatic arthritis. Arch Dermatol 2010, 146, 721-726.

20. Choe J.Y., Bae J., Jung H.Y., Park S.H., Lee H.J., Kim S.K.: Serum resistin level is associated with radiographic changes in hand osteoarthritis: cross-sectional study. Joint Bone Spine 2012, 79, 160-165.

21. Love T.J., Zhu Y., Zhang Y., Wall-Burns L., Ogdie A., Gelfand J.M., et al.: Obesity and the risk of psoriatic arthritis: a population-based study. Ann Rheum Dis 2012, 71, 1273-1277.

22. Kim G.K., Del Rosso J.Q.: Drug-provoked psoriasis: is it drug-induced or drug - aggravated? Understanding pathophysiology and clinical relevance. J Clin Aesrhetic Dermatol 2010, 3, 32-38.

23. Busse K., Liao W.: Which psoriasis patients develop psoriatic arthritis? Psoriasis Forum 2010, 16, 17-25

24. Kerschbaumer A., Fenzl K.A., Erlacher L., Aletaha D.: An overview of psoriatic arthritis - epidemiology, clinical features, pathophysiology and novel treatment targets. Wien Klin Wochenschr 2016, 128, 791-795.

25. de Vlam K., Gottkieb A.B., Philip J., Mease P.J.: Current concepts in psoriatic arthritis: pathogenesis and management. Acta Dermatol Venerol 2014, 94, 627-634.

26. Coates L.C., Kavanaugh A., Mease P.J., Soriano E.R., Laura Acosta-Felquer M., Armstrong A.W., et al.: Group for Research and Assessment of Psoriasis and Psoriatic Arthritis 2015 Treatment Recommendations for Psoriatic Arthritis. Arthritis Rheumatol 2016, 68, 1060-1071.

27. Moll J.M., Wright V.: Psoriatic arthritis. Semin Arthritis Rheum 1973, 3, 55-78.

28. Coates B., Glossec L., Ramiro S., Mease P., Heijde D., Smolen J.S., et al.: New GRAPPA and EULAR recommendations for the management of psoriasis arthritis. Rheumatology 2017, 56, 1251-1253.

29. Taylor W., Gladman D., Helliwell P., Marchesoni A., Mease P., Mielants H.; CASPAR Study Group.: Classification criteria for psoriatic arthritis: development of a new criteria from a large international study. Arthritis Rheum 2006, 54, $2665-2673$.

30. Coates L.C., Helliwell P.S.: Psoriatic arthritis: state of the art review. Clin Med 2017, 17, 65-70.

31. Akgul O., Ozgocmen S.: Classification criteria for spondyloarthropathies. World J Orthop 2011, 2, 107-115. 
32. Villani A.P., Rouzaud M., Sevrain M., Barnetche T., Paul C., Bedylot-Barry M., et al.: Symptoms dermatologists should look for in daily practice to improve detection of psoriatic arthitis in psoriasis patients: an expert group consensus. J Eur Acad Dermatol Venerol 2014, 28, 27-33.

33. Ritchlin C.T., Kavanaugh A., Gladman D.D.: Treatment recommendations for psoriatic arthritis. Ann Rheum Dis 2009, 68, 1387-1394.

34. Al-Yasiri A.R., Yasir S.: The Validity of Beck Depression Inventory - Short Version in Depressed Patients Diagnosed According to ICD10. Iraqi Postgrad Med J 2013, 12.

35. Roussou E., Shahzabeen S.: The Bath Ankylosing Spondylitis Activity and Function Indices (BASDAI and BASFI) and their correlation with main symptoms experienced by patients with spondyloarthritis. Clin Rheumatol 2010, 29, 869-874.

36. Joshi A., Kale S., Chandel S., Pal D.K.: Likert scale: explored and explained. Curr J Appl Sci Technol 2015, 7, 396-403.

37. Helliwell P.S., Taylor W.: Classification and diagnostic criteria for psoriatic arthritis. Ann Rheum Dis 2005, 64, 3-8.

38. Mease P.J., Armstrong A.W.: Managing patients with psoriatic disease: the diagnosis and pharmacologic treatment of psoriatic arthritis in patients with psoriasis. Drugs 2014, 74, 423-441.

39. Husni M.E., Meyer K.H., Cohen D.S., Mody E., Qureshi A.A.: The PASE questionnaire: pilot testing a psoriatic arthritis screening and evaluation tool. J Am Acad Dermatol 2007, 57, 581-587.

40. Ibrahim G.H., Buch M.H., Lawson C., Waxman R., Helliwell P.S.: Evaluation of an existing screening tool for psoriatic arthritis in people with psoriasis and the development of a new instrument: the Psoriasis Epidemiology Screening Tool (PEST) questionnaire. Clin Exp Rheumatol 2009, 27, 469-474.

41. Tom B.D., Chandran V., Farewell V.T., Rosen C.F., Gladman D.D.: Validation of the Toronto Psoriatic Arthritis Screen Version 2 (ToPAS 2). J Rheumatol 2015, 42, 841-846.

42. Mishra S., Kancharla H., Dogra S., Sharma A.: Comparison of four validated psoriatic arthritis screening tools in diagnosing psoriatic arthritis in patients with psoriasis (COMPAQ Study). Br J Dermatol 2017, 176, 765-770.

43. Coates L.C., Hodgson R., Conaghan P.G., Freeston J.E.: MRI and ultrasonography for diagnosis and monitoring of psoriatic arthritis. Bedst Prac Res Clin Rheumatol 2012, 26, 805-822.

44. Jadon D.R., Sengupta R., Nightingale A., Lindsay M., Korendowych E., Robinson G., et al.: Axial Disease in Psoriatic Arthritis study: defining the clinical and radiographic phenotype of psoriatic spondyloarthritis. Ann Rheum Dis 2017, 76, 701-707.

45. Schwenzer N.F., Kotter I., Henes J.C., Schraml C., Fritz J., Claussen C.D., et al.: The role of dynamic contrast-enhanced MRI in the differential diagnosis of psoriatic and rheumatoid arthritis. Am J Roentgenol 2010, 194, 715-720.

46. Combe B., Landewe R., Daien C.I., Hua C., Aleaha D., Alvaro-Gracia J.M., et al.: 2016 update of the EULAR recommendations for the management of early arthritis. Ann Rheum Dis 2017, 76, 948-959.

47. Salaffi F., Ciapetti A.: Clinical disease activity assessments in rheumatoid arthritis. Int J Clin Rheumatol 2013, 8, 347-360.

48. Schoels M.M., Aletaha D., Alasti F., Smolen J.S.: Disease activity in psoriatic arthritis (PsA): defining remission and treatment success using the DAPSA score. Ann Rheum Dis 2016, 75, 811-818.

49. Helliwell P.S., Waxman R.: Modification of the Psoriatic Arthritis Disease Activity Score (PASDAS). Ann Rheum Dis 2018, 77, 467-468.

50. Wong P.C., Leung Y.Y., Li E.K., Tam L.S.: Measuring disease activity in psoriatic arthritis. Int J Rheumatol 2012, $2012,839425$.

51. Kavanaugh A., Cassell S.: The assessment of disease activity and outcomes in psoriatic arthritis. Clin Exp Rheumatol 2005, 23, 142-147.

Received: 5.01 .2018

Accepted: 6.01 .2020

Otrzymano: 5.01.2018 r.

Zaakceptowano: $6.01 .2020 \mathrm{r}$.

How to cite this article

Chabros P., Pietrzak A., Gągała J., Kandzierski G., Krasowska D.: Psoriatic arthritis - classification, diagnostic and clinical aspects. Dermatol Rev/Przegl Dermatol 2020, 107, 32-43. DOI: https://doi.org/10.5114/dr.2020.93969. 